\title{
Determinants of Fear of Demographic Changes and the Tendency to Spread Viral News Among Millennials
}

\author{
Muhammad Wahyuddin Abdullah', Alim Syariati² \\ ${ }^{1}$ Accounting Department, Universitas Islam Negeri Alauddin, Indonesia \\ ${ }^{2}$ Economics Department, Universitas Islam Negeri Alauddin, Indonesia \\ Corresponding Author's Email: alim.syariati@uin-alauddin.ac.id
}

\begin{abstract}
Tendency of spreading viral news had become quite a problem in itself, as the information mostly was not authorized, and could trigger the fear of structural changes in the society. This study aimed to investigate whether political preference, religiosity, and group chat involvements affected the tendency to spread viral news, and ultimately led to fear of demographic changes. Quantitatively, 170 youths participated in this study and were analyzed in SEM-PLS. The study found that millennials' political preference affected their news dissemination; involvement in group chats also increased their news channeling. Interestingly, religious millennials feared the shift in demographics. Aside from that acceptance, other hypotheses were rejected. This contributed to the discussion of communication among millennials.
\end{abstract}

Keywords: viral news, millennials, demographic changes

\section{INTRODUCTION}

Indonesia is a huge market for social media and instant messaging applications. In 2015, users of the instant messaging application are estimated to be 52.1 million users and expected to grow to 86 million users (Statista 2018). Emarketer in 2016 projected the users of the mobile messaging app will reach 91.6 million users, or equal to $34.6 \%$ of the Indonesian population. A survey by Dailysocial in 2017 showed that WhatsApp has topped the use of messaging app in Indonesia, toppling BBM as the leader in 2016, as data from Statista in 2017 revealed that $40 \%$ of the population used Whatsapp as their preferred chat application.

These huge numbers reveal a holy grail. As the benefit grows, the negative aspects also follow. A study in 2012 by Sabatini and Sarracino demonstrated the negative impact of the internet. The study found the more people are absorbed in social media, the more their subjective well-being deteriorated. 50000 people in Italy who participated in that survey revealed the negative effects of social media were the rise of hate speech, social distrust, cyberbullying, identity theft, cyber- 
stalking, explicit or violent imagery, sharing too much, online grooming, emotional negativities, and lack of interpersonal skills (Sabatini \& Sarracino, 2014).

Another aspect to discuss in this study is the fear of demographic changes. The experience of white Americans who worried about the projections of them being a minority is imminent (Outten, Schmitt, Miller, \& Garcia, 2012). Such fear of shifts was even more magnified in the current Trump administration (Huber, 2016). This condition is also apparent in Indonesia. Post-2014 election, such fear created a push to the intensity between races, where the majority felt threatened over China's political agenda, or even those who were deemed, non-natives. The Basuki Tjahaya Purnama's (Ahok) blasphemy case also put the condition even worst (Herdiansah, Putri, Ashari, \& Maduratmi, 2017; Lim, 2017). This is what we call fear of demographic changes.

The study in these topics was mostly taking general information; however, this study contributed to the knowledge enrichment by taking the perspectives of millennials. The proposed relationships in this research were also exploratory in nature and built upon the logic of action and consequences. Therefore, some relationships of variables were also just recently used, giving it a unique standing.

This study is particularly important, as it is critical to provide insights into the use of messaging apps in spreading viral news. Specifically, we aimed to investigate the millennials' preference in forwarding viral or attractive news (even fake news), by several factors, such as political preference (Liberal), religiosity (conservative), and involvement in group chats. We also investigate those relationships to fear of demographic changes, directly and indirectly, in hope of small contributions in the communication field.

\section{LITERATURE REVIEW Political Preference}

Human is subject to emotion. Their moral value is a clue as to accept a condition or not. Despite oversimplification, being liberal or conservative makes things easier to assess the psychology of human beings. Thus, this study proposes the political preference of millennials into conservative or liberal. While in the USA it is easier to divide them as Republican to conservative and Democrat to liberal, It is hard to classify one into these groups. Politics could be defined as institutions, norms, and management constructed for all stakeholders (Caprara \& Zimbardo, 2004). Liberal view pursue freedom of acting as its background, and optimistic belief in regard of life, while endorsing human being true to nature; on the other hand, conservative people belief people in pessimistic view, and thus need constraints, law, civic rule, or even strict rule to govern human being (Graham, Haidt, \& Nosek, 2009). Haidt and Graham believed that the moral code of conservative people was more abundant than liberal, as they are more open to changes and hate restrictions (Haidt \& Graham, 2007). This study grouped political preference in the liberal view, in its items.

Conservative people with their rich moral conduct tended to feel easily disgusted or even attacked with new trends, phenomena, or changes. Both liberals and conservatives used media in rich ways. They both distributed information in the 
pattern of their likings, or political agenda (Hargittai, Gallo, \& Kane, 2008). As liberals were more open to changes, they held little fear over changes of shifts in demographics. This condition would provide the basis for:

H1: Liberal political preference would distribute news in no difference to conservatism.

H4: Liberal political preference would not fear the shifts in demographics.

H8: An indirect relationship would form between political preference, tendency to spread news, and fear of demographic changes

\section{Religiosity}

Clifford Geertz defined religion as a system of symbols that apply $\mathrm{W}$ and encapsulating these concepts with a kind of jet factuality, so that the mood and motivation look realistic (Geertz, 2013). By the word of religion, the term of religiosity was introduced to include five dimensions, such as ideological, ritualistic, experience, intellectual, and the consequential dimension (Glock, 1962). Religion was expected to provide an internal control for self-monitoring in moral behavior (Anderson \& Tollison, 1992). Millennials' spirituality provided a good foundation for many life needs (Haerani, Parmitasari, Aponno, \& Aunalal, 2019; Parmitasari, Alwi, \& S., 2018).

Religious people were actively promoting their beliefs. As they are commonly closer to conservative values, they would easily felt disgusted to others that contradicted their moral values (Inbar, Pizarro, \& Bloom, 2009). They would cluster themselves in the efforts to propagate their ideas (Hargittai et al., 2008). These feeling of disgusted would be channeled toward things that were against their value, thus:

H2: Religious millennials tended to actively spread the news.

H5: Millennials with strong religiosity would fear the demographic shifts

H9: An indirect link would form between religiosity, fear of demographic changes, and tendency to spread the news.

\section{Group Chat Involvements}

Participation in group chats was a common fact in rich mobile chat applications. One explanation could come from the information gap theory, in which an action occurred when the feeling of knowledge deprivation emerged (Loewenstein, 1994). As the involvement in group chats increased, people could face overloaded information (Hargittai et al., 2008; Nematzadeh, Ciampaglia, Ahn, \& Flammini, 2016), and even created trusts over longer texts of information (Berger \& Milkman, 2012). If such involvements created a conservative community where false news was distributed actively, this could increase the belief that something is right, despite they are wrong (Rainie \& Duggan, 2015). A study in Indonesia revealed that $44.3 \%$ of people received a piece of unfiltered information; furthermore, $62.8 \%$ obtained that information through a chat application, and $47.1 \%$ from close relatives (MASTEL, 2017). This provided the foundations to the following hypotheses:

H3: The more millennials involved in group chats, their tendency to disseminate information also increased.

H6: Clustering in group chats increased the fear of demographic shifts. 
H10: An indirect relationship would emerge from group chat involvements, tendency to spread news, and fear of demographic changes.

\section{The tendency to Spread News}

Why people spread the news? the theory of Interpersonal Communication was first introduced by American Psychologist William Schutz in 1958. It discussed why people shared common information. In the study, he formulated three conditions of why people share some contents, namely inclusion, affection, and control. Inclusion is a need to obtain satisfaction in a way that contributes fully/useful after interacting in groups. Inclusion satisfied the desire for recognition of one's ego of having certain knowledge or ability. Affection is a strong desire to maintain a relationship with others as a form of likeness or personal feelings. Finally, control is the tendency to dominate a conversation or even information in a group that ultimately could fill the room with the desired knowledge (Atelsek \& Schutz, 1959). Using this theory, Ho and Dempsey discovered that inclusion and affection were the two dominant factors to share stories with others (Ho \& Dempsey, 2010). This theory became the foundation of information transmission in this study.

The question is certainly whether such a tendency to distribute the information could increase the fear of demographic shift. A study provided the recipe to be viral or the most shared news was the length of the story itself. Longer information tended to be more shared than the short one (Berger \& Milkman, 2012). This is in line with the phenomenon in WhatsApp group chats that oftentimes, the large number of long posts were distributed. The shared information was not even verified. Negative or hoax news was commonly shared in this platform, even in lecturer group chats. A filter to block fake news had to be maintained by the group admin (Kurniasih \& Riyadhsyah, 2018). A survey from Masyarakat Telekomunikasi Indonesia found that unfiltered news could harm the stability of the Indonesian community (MASTEL, 2017), as it could trigger insecurity among citizens and even affect the political agenda (Salman et al., 2016). Certainly, we could not deny the benefit of having good social media as a control to the administration (Raja Zulkifi, Mohd Sani, Muhamad, \& Ahmad, 2018). This provided a basis for the following hypothesis:

H7: As more information is shared through chat applications, the higher the potentiality of the increased fear of demographic shift.

\section{METHODOLOGY}

This study is planned to employ structural equation modeling to assess these research questions quantitatively. Several studies above used descriptive approaches and others employed regression. Structural modeling is actually just a regression method but improved to capture the statements in higher dimensions. This research tries to obtain responses from the youth, or Muslim millennials, as they have certain characteristics, relax, fun, etc. This would provide great information, in regard to how they interact in the chat application.

Data will be obtained through online and offline means. This study will 
forward questionnaires through a google form, and other WhatsApp groups of millennials with a minimum sample of 150 people. The offline methods by face-toface questionnaires would also be conducted to achieve larger data responds. Data will then be analyzed descriptively and inferentially. The selection of which SEM to use would be determined after testing the normality of the data. If the data is normal, then CB-SEM is employed, otherwise PLS-SEM. Each method required different approaches. After discussing the findings, the discussion section will follow. Thus, we proposed this conceptual framework as:

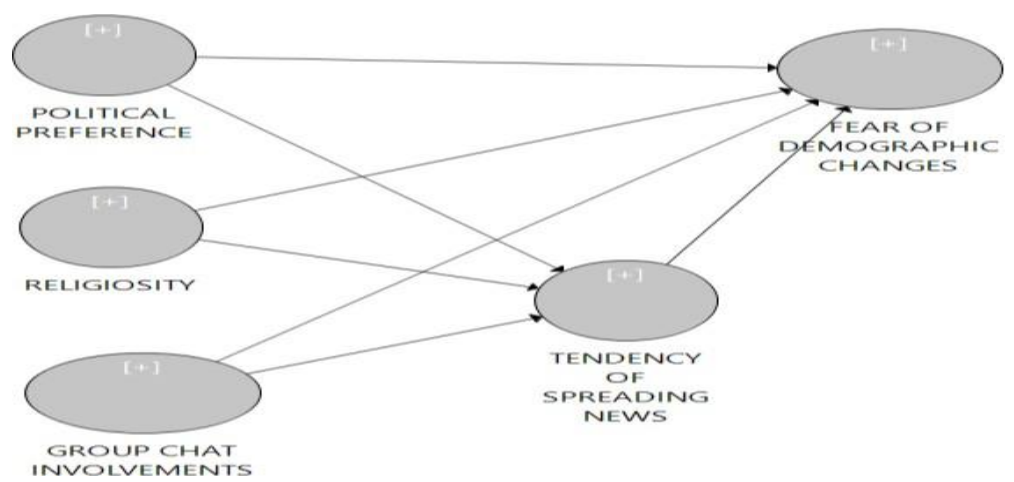

Figure 1. Conceptual Framework

\section{RESULTS AND DISCUSSION}

\section{Results}

This study aimed to investigate the issue of chat application uses among youth in Makassar, specifically those who were still in college. 170 striplings participated in this study and divided into several descriptive criteria as follows:

\begin{tabular}{|l|c|c|}
\hline Descriptions & n & \% \\
\hline Sex & 50 & $29.4 \%$ \\
\hline Male & 120 & $70.6 \%$ \\
\hline Female & \multicolumn{3}{|l|}{} \\
\hline Age of respondents: Mostly under 25 (80\%) \\
\hline Tribes \\
\hline Buginese & 93 & 54.7 \\
\hline Makassar & 30 & 17.6 \\
\hline Others & 47 & 38.2 \\
\hline
\end{tabular}

Table 1. Profile of Respondents

From the table above, it could be easily seen that ladies dominated the response in this study. As we targeted the millennials as the respondents, we constrained the questionnaires only to those above 15, and under 25 years old. This study also took place in Makassar, South Sulawesi, Indonesia, as such most of the respondents were Buginese, meaning most of the respondents were not local residents of Makassar, despite Makassar came second in response. By the above 
descriptions, it could be assumed that our data-target had been met.

The next agenda was to choose the appropriate Structural Equation Modelling (SEM) being employed. Based on the data, SEM consisted of two kinds, e.g. covariance-based SEM (CB-SEM) and partial least square SEM (PLS-SEM). CBSEM worked with normally-distributed data, and PLS-SEM otherwise (Ketchen, 2013). PLS-SEM also could work with a small size of data, contrary to CB-SEM. By those conditions, we run a normality test on the obtained data, and find as follows:

\begin{tabular}{|c|rc|}
\hline & \multicolumn{3}{|c|}{ Skewness and Kurtosis } \\
Variable & Chi-Square & P-Value \\
x11 & 48.251 & 0.000 \\
x12 & 12.474 & 0.002 \\
x13 & 18.480 & 0.000 \\
x14 & 18.709 & 0.000 \\
x15 & 18.673 & 0.000 \\
x21 & 112.011 & 0.000 \\
x22 & 10.600 & 0.005 \\
x23 & 18.904 & 0.000 \\
x24 & 17.850 & 0.000 \\
x25 & 2.057 & 0.357 \\
x31 & 3.362 & 0.186 \\
x32 & 8.206 & 0.017 \\
x33 & 2.898 & 0.235 \\
x34 & 3.199 & 0.202 \\
y1 & 36.783 & 0.000 \\
y2 & 18.163 & 0.000 \\
y3 & 15.180 & 0.001 \\
y4 & 3.492 & 0.174 \\
z1 & 12.522 & 0.002 \\
z2 & 5.185 & 0.075 \\
z3 & 9.390 & 0.009 \\
z4 & 12.213 & 0.002 \\
z5 & 19.551 & 0.000 \\
\hline
\end{tabular}

Table 2. Normality tests (Lisrel Output)

The normality results above revealed that the majority of items were significant with a p-value under 0.05 , indicating data were not normally distributed. This provided support to use PLS-SEM as the statistical tool. The benefit of using this method was it had fewer assumptions and higher statistical power. It also was characterized as a statistical tool for theory exploration with non-parametric nature, instead of theory confirmation in CB-SEM (Hair, Risher, Sarstedt, \& Ringle, 2019). As our study was also had an exploratory nature, it provided a better ground to use the technique.

In selecting this method, several steps had to be taken into account before revealing the obtained hypothesis answer. Evaluation of outer models needed to be conducted before running the structural modeling. Four criteria were internal consistency reliability, indicator reliability, convergent validity, and discriminant validity (Ketchen, 2013). A summary of the results was as follows: 


\begin{tabular}{|c|c|c|c|c|c|}
\hline $\begin{array}{c}\text { Latent } \\
\text { Variables }\end{array}$ & Item Markers & $\begin{array}{l}\text { Loading } \\
\text { factors }\end{array}$ & $\begin{array}{l}\text { Composite } \\
\text { Reliability }\end{array}$ & $\begin{array}{l}\text { Cronbach's } \\
\text { Alpha }\end{array}$ & AVE \\
\hline \multirow{5}{*}{$\begin{array}{l}\text { Political } \\
\text { preferences }\end{array}$} & $\mathrm{X} 11$ & 0,592 & \multirow{5}{*}{0,772} & \multirow{5}{*}{0,602} & \multirow{5}{*}{0,583} \\
\hline & $\mathrm{X} 12$ & 0,698 & & & \\
\hline & $\mathrm{X} 13$ & 0,711 & & & \\
\hline & $\mathrm{X} 14$ & 0,670 & & & \\
\hline & $\mathrm{X} 15$ & 0,092 & & & \\
\hline \multirow{5}{*}{ Religiosity } & $\mathrm{X} 21$ & 0,242 & \multirow{5}{*}{0,875} & \multirow{5}{*}{0,811} & \multirow{5}{*}{0,637} \\
\hline & $\mathrm{X} 22$ & 0,648 & & & \\
\hline & $\mathrm{X} 23$ & 0,784 & & & \\
\hline & $\mathrm{X} 24$ & 0,487 & & & \\
\hline & $\mathrm{X} 25$ & 0,735 & & & \\
\hline \multirow{4}{*}{$\begin{array}{l}\text { Group chat } \\
\text { involvements }\end{array}$} & X31 & 0,811 & \multirow{4}{*}{0,704} & \multirow{4}{*}{0,563} & \multirow{4}{*}{0,506} \\
\hline & X32 & 0,799 & & & \\
\hline & X33 & 0,800 & & & \\
\hline & X34 & 0,783 & & & \\
\hline \multirow{4}{*}{$\begin{array}{l}\text { Tendency to } \\
\text { spread news }\end{array}$} & Y1 & 0,726 & \multirow{4}{*}{0,728} & \multirow{4}{*}{0,560} & \multirow{4}{*}{0,575} \\
\hline & Y2 & 0,575 & & & \\
\hline & Y3 & 0,679 & & & \\
\hline & Y4 & 0,688 & & & \\
\hline \multirow{5}{*}{$\begin{array}{l}\text { Fear of } \\
\text { demographic } \\
\text { changes }\end{array}$} & $\mathrm{Z1}$ & 0,538 & \multirow{5}{*}{0.812} & \multirow{5}{*}{0,713} & \multirow{5}{*}{0,462} \\
\hline & $\mathrm{Z} 2$ & 0,781 & & & \\
\hline & $\mathrm{Z3}$ & 0,835 & & & \\
\hline & $\mathrm{Z4}$ & 0,529 & & & \\
\hline & Z5 & 0,538 & & & \\
\hline
\end{tabular}

Table 3. Outer Model Measurements

The finding in the initial steps above depicted troublesome data. Several data had a low loading factor as well as Cronbach's alpha. However, the composite reliability of each variable had been proven to be good as they were higher than 0.70 thresholds. The most desired loading factor and Cronbach's alpha were above 0.70 , despite Hair suggested not to delete the items unless they were less than 0.5 or the deletion did not improve the Cronbach's alpha and the Average Variance Extractor (AVE) (Hair et al. 2014:107). Following that result, we deleted several items with low loadings, such as items x11, x15, x21, x 24 , and $\mathrm{z} 4$ to remedy the findings. After deletion, better results were obtained.

After the outer loading value obtained is in accordance with the specified standards, the next test in the convergence validity test is the Average Variance Extracted Test (AVE). AVE means the mean value of the variable being tested. The standard of AVE is 0.50 or more which indicates that the research construct tested 
can explain the variance of the indicator by more than half and vice versa. Lower results indicate a higher error value than the construct based on the value of the variance. From the calculation, it was clear that only one variable of fear of demographic changes that did not meet the 0.5 thresholds. This result was definitely an improvement. The variable with low AVE was still usable as long as the composite reliability was higher than 0.7 (Fornell \& Larcker, 1981). This academic opinion led to the convincement of convergence validity of the data and could be proceeded into the next step, the discriminant validity tests.

Discriminant validity test is the next stage which is carried out with the aim to find out whether the variables or indicators in our research have unique values and are only related to the variables or indicators themselves and not from variables or indicators outside of which they are represented. Two measures were used in the test, namely the cross-loading test and the Fornell-Larcker criterion test. The first result of the cross-loading test was as follows:

\begin{tabular}{|l|r|r|r|r|r|}
\hline ITEMS & $\begin{array}{l}\text { POLI. } \\
\text { PREFF. }\end{array}$ & RELIGIOSITY & $\begin{array}{l}\text { GROUP } \\
\text { C.I. }\end{array}$ & $\begin{array}{l}\text { TENDENCY } \\
\text { OF S.N. }\end{array}$ & $\begin{array}{l}\text { FEAR } \\
\text { OF D.C. }\end{array}$ \\
\hline $\mathbf{x 1 2}$ & $\mathbf{0 , 6 3 8}$ & 0,113 & 0,236 & 0,230 & 0,033 \\
\hline $\mathbf{x 1 3}$ & $\mathbf{0 , 7 3 4}$ & 0,234 & 0,164 & 0,190 & 0,163 \\
\hline $\mathbf{x 1 4}$ & $\mathbf{0 , 7 5 6}$ & 0,214 & 0,154 & 0,283 & 0,166 \\
\hline $\mathbf{x 2 2}$ & 0,198 & $\mathbf{0 , 7 3 0}$ & 0,042 & 0,161 & 0,199 \\
\hline $\mathbf{x 2 3}$ & 0,210 & $\mathbf{0 , 8 1 6}$ & $-0,006$ & 0,198 & 0,291 \\
\hline $\mathbf{x 2 5}$ & 0,204 & $\mathbf{0 , 7 2 6}$ & 0,137 & 0,204 & 0,229 \\
\hline $\mathbf{x 3 1}$ & 0,192 & 0,104 & $\mathbf{0 , 8 1 6}$ & 0,332 & 0,152 \\
\hline $\mathbf{x 3 2}$ & 0,215 & 0,096 & $\mathbf{0 , 8 0 1}$ & 0,273 & 0,066 \\
\hline $\mathbf{x 3 3}$ & 0,160 & $-0,013$ & $\mathbf{0 , 7 9 4}$ & 0,269 & 0,100 \\
\hline $\mathbf{x 3 4}$ & 0,232 & 0,037 & $\mathbf{0 , 7 8 1}$ & 0,330 & 0,065 \\
\hline $\mathbf{y 1}$ & 0,182 & 0,220 & 0,214 & $\mathbf{0 , 7 4 4}$ & 0,219 \\
\hline $\mathbf{y 2}$ & 0,106 & 0,006 & 0,445 & $\mathbf{0 , 5 2 1}$ & $-0,158$ \\
\hline $\mathbf{y 3}$ & 0,156 & 0,024 & 0,390 & $\mathbf{0 , 6 3 6}$ & 0,014 \\
\hline $\mathbf{y 4}$ & 0,264 & 0,240 & 0,236 & $\mathbf{0 , 7 0 6}$ & 0,193 \\
\hline $\mathbf{y 5}$ & 0,352 & 0,252 & 0,158 & $\mathbf{0 , 7 6 3}$ & 0,374 \\
\hline $\mathbf{z 1}$ & 0,219 & 0,196 & 0,113 & 0,261 & $\mathbf{0 , 6 7 5}$ \\
\hline $\mathbf{z 2}$ & 0,090 & 0,213 & 0,046 & 0,183 & $\mathbf{0 , 8 0 2}$ \\
\hline $\mathbf{z 3}$ & 0,094 & 0,314 & 0,113 & 0,122 & $\mathbf{0 , 8 0 7}$ \\
\hline
\end{tabular}

Table 4. Cross Loading measures

The results of data processing show the results of the cross-loading of this study. Each bold character must have a greater value than the column or row that is not colored to be discriminant valid. It is clear that the entire highlighted numbers have a greater value than the indicator or even other variables. Therefore, the results of the assessment of indicators and variables based on the cross-loading criteria are declared to be discriminant validity. The next more conservative test is the FornellLarcker measure. The results obtained are as follows: 


\begin{tabular}{|c|c|c|c|c|c|}
\hline VARIABLES & $\begin{array}{c}\text { Fear of } \\
\text { D.C. }\end{array}$ & $\begin{array}{c}\text { Group } \\
\text { C.I. }\end{array}$ & $\begin{array}{c}\text { Poli. } \\
\text { Preff }\end{array}$ & Religiosity & $\begin{array}{c}\text { The } \\
\text { tendency } \\
\text { of S.N. }\end{array}$ \\
\hline $\begin{array}{c}\text { Fear Of Demographic } \\
\text { Changes }\end{array}$ & $\mathbf{0 , 7 6 4}$ & & & & \\
\hline $\begin{array}{c}\text { Group Chat } \\
\text { Involvements }\end{array}$ & 0,123 & $\mathbf{0 , 7 9 8}$ & & & \\
\hline Political Preference & 0,179 & 0,251 & $\mathbf{0 , 7 1 1}$ & & \\
\hline Religiosity & 0,321 & 0,073 & 0,268 & $\mathbf{0 , 7 5 9}$ & \\
\hline $\begin{array}{c}\text { Tendency Of } \\
\text { Spreading News }\end{array}$ & 0,247 & 0,381 & 0,335 & 0,249 & $\mathbf{0 , 6 8 0}$ \\
\hline
\end{tabular}

Table 5. Fornel Larcker Criterion

Fornell-Larcker Criteria Test compares the square root of the AVE value with the correlation of other latent variables. The eligibility criteria of this test are the square root value of AVE must show a greater value related to the construct itself compared to other variables. Based on the test results above, it can be observed that all variables have a higher value when explaining the variable itself compared to the others. The conclusion that can be drawn based on the Fornell-Larcker criterion test in this study is that the value of variance from the data is more explained by the construct itself compared to other constructs that are supposed to have no relationship.

Once the model proposed in the study meets the validity and reliability of reflective standards, the structural model testing can be carried out. Unlike the CBSEM analysis which uses the goodness of fit based on the comparison of data covariance criteria, SEM-PLS uses a heuristic-based method that is determined by the predictive ability of the model. SEM-PLS assumes the proposed model is correct and hence the data is processed with the aim of predicting how well the model predicts endogenous variables. To assess the feasibility of the model, this study assessed three steps, namely: (1) Assessment of the multicollinearity impact of structural models; (2) An assessment of the relationship between the structural model of significance and relevance; (3) The $\mathrm{R}^{2}$.

\begin{tabular}{|l|l|r|}
\hline \multicolumn{1}{|c|}{ Variables } & $\begin{array}{l}\text { Fear of Demographic } \\
\text { Changes }\end{array}$ & $\begin{array}{l}\text { The tendency of } \\
\text { Spreading News }\end{array}$ \\
\hline Fear Of Demographic Changes & & 1,067 \\
\hline Group Chat Involvements & 1,197 & 1,144 \\
\hline Political Preference & 1,201 & 1,078 \\
\hline Religiosity & 1,115 & \\
\hline Tendency Of Spreading News & 1,303 & \\
\hline
\end{tabular}

Table 6. Inner VIF Values 
The first step to analyze the inner model was the multicollinearity test. This analysis tests accepted the tolerance values below 0.20 or VIF above 5.00. If the value obtained is below or above the required value, it is recommended to delete the construct, combine the dimensions into one dimension, or create a new construct to handle the collinearity. The results of data processing produce VIF values as table above.

\begin{tabular}{|l|l|}
\hline \multicolumn{1}{|c|}{ Items } & VIF \\
\hline $\mathrm{x} 12$ & 1,168 \\
\hline $\mathrm{x} 13$ & 1,231 \\
\hline $\mathrm{x} 14$ & 1,084 \\
\hline $\mathrm{x} 22$ & 1,294 \\
\hline $\mathrm{x} 23$ & 1,315 \\
\hline $\mathrm{x} 25$ & 1,174 \\
\hline $\mathrm{x} 31$ & 1,907 \\
\hline $\mathrm{x} 32$ & 1,984 \\
\hline $\mathrm{x} 33$ & 1,854 \\
\hline $\mathrm{x} 34$ & 1,719 \\
\hline $\mathrm{y} 1$ & 1,461 \\
\hline $\mathrm{y} 2$ & 1,418 \\
\hline $\mathrm{y3}$ & 1,494 \\
\hline $\mathrm{y} 4$ & 1,312 \\
\hline $\mathrm{y} 5$ & 1,459 \\
\hline $\mathrm{z} 1$ & 1,099 \\
\hline $\mathrm{z} 2$ & 1,613 \\
\hline $\mathrm{z} 3$ & 1,554 \\
\hline
\end{tabular}

Table 7. Outer VIF Values

The multicollinearity test results of the model provided convincing results on the feasibility of the elements of the model. VIF values either from the relationship between exogenous and endogenous variables, or the relationship between indicators in explaining latent variables also reach average values above 1 and below 2.5. Based on the standard of VIF eligibility value between $0.20-5$, then the whole model is declared as not having multicollinearity and can be continued to the next stage.

The structural model coefficient test is the next important phase where the relationship between variables is evaluated. In other words, this test dissects the strength of the relationship and the direction of the variables. The method of evaluating the significance of the relationship in the proposed model depends on the standard error obtained through the bootstrapping process. This step calculates the standard error statistics to obtain the empirical results of the $t$ value by comparing the path coefficient estimate with the standard bootstrap error. The requirements proposed in the book of Hair et al. (2014: 171) is the sample must be greater than 30 to be declared worthy of further testing. The results of the $t$ value will be compared with the critical value standard for the acceptance of the proposed model empirically. The critical values are generally (1) 1.65 for a significance level of $10 \%$, or a variable capable of explaining $90 \%$ prediction of a relationship; (2) 
1.96 for the 5\% significance level; and (3) 2.57 for the $1 \%$ significance level. The result was as follows:

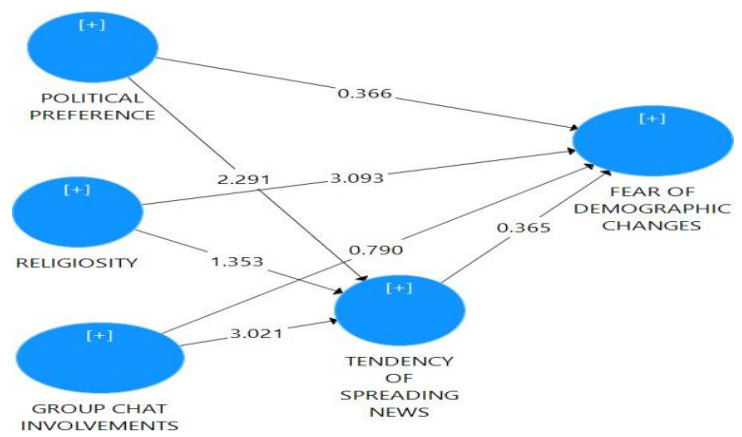

Figure 1. Bootstrap result

\begin{tabular}{|c|c|c|c|}
\hline Relationships & $\begin{array}{c}\text { T- } \\
\text { values }\end{array}$ & P-values & Hypothesis \\
\hline $\begin{array}{l}\text { Political preference of spreading } \\
\text { news }\end{array}$ & 2,291 & 0,022 & $\begin{array}{c}\mathrm{H} 1 \\
\text { accepted }\end{array}$ \\
\hline $\begin{array}{c}\text { Religiosity tendency } \boldsymbol{d} \\
\text { spreading news }\end{array}$ & 1,353 & 0,176 & $\mathrm{H} 2$ rejected \\
\hline $\begin{array}{l}\text { Group chat involvements } \\
\text { tendency of spreading news }\end{array}$ & 3,021 & 0,003 & $\begin{array}{c}\mathrm{H} 3 \\
\text { accepted }\end{array}$ \\
\hline $\begin{array}{l}\text { Political preference fear } \\
\text { demographic changes }\end{array}$ & 0,437 & 0,662 & $\begin{array}{c}\mathrm{H} 4 \\
\text { accepted }\end{array}$ \\
\hline $\begin{array}{l}\text { Religiosity fear } \\
\text { demographic changes }\end{array}$ & 3,566 & 0,000 & $\begin{array}{c}\mathrm{H} 5 \\
\text { accepted }\end{array}$ \\
\hline $\begin{array}{l}\text { Group chat involvements } \\
\text { fear of demographic changes }\end{array}$ & 1,154 & 0,249 & H6 rejected \\
\hline $\begin{array}{l}\text { Tendency of spreading news Fear } \\
\text { of demographic changes }\end{array}$ & 0,365 & 0,715 & H7 rejected \\
\hline $\begin{array}{l}\text { Political preference of changes } \\
\text { the tendency of } \\
\text { News }\end{array}$ & 0,328 & 0,743 & H8 rejected \\
\hline $\begin{array}{l}\text { Religiosity fear of changes } \\
\text { tendency of sp. } \\
\text { News. }\end{array}$ & 0,270 & 0,787 & H9 rejected \\
\hline $\begin{array}{l}\text { Group chat inv. fear dlem. } \\
\text { Changes the of sp. News. }\end{array}$ & 0,370 & 0,711 & $\begin{array}{l}\mathrm{H} 10 \\
\text { rejected }\end{array}$ \\
\hline
\end{tabular}

Table 8. Summary of Hypothesis Testing (PLS-SEM output) 
The result presented above revealed the answer to the proposed hypothesis. Specifically, this study hypothesized the influence between variables in the form of direct and indirect relationships would be tested at a significance level of $5 \%$. There are 10 hypotheses proposed and the following was a summary of the significance tests between these variables in detail:

The table above clearly displays the answers to the proposed hypotheses. Several hypotheses were accepted, and most of them were rejected. This study found that from a total of 10 hypotheses, only 3 alternative hypotheses were accepted. Consequently, our findings indicate that political preferences affect the tendency of spreading the news (H1 is accepted). Religious factors did not affect the tendency of spreading the news (H2 was rejected). Group chat involvements can increase the tendency of spreading the news (H3 accepted). The political preference of millennial generation has no significant impact on their fear of demographic changes because the liberals (as this study constructed political preference) were more open to other opinions or changes than conservatives whom more easily disgusted (H4 accepted) (Inbar et al., 2009). However, religious factors are able to encourage the millennial generation to fear demographic changes (H5 accepted). Involvement in many chat groups was apparently not able to encourage students to fear demographic change (H6 was rejected). The tendency of students to spread the news also did not increase their fear of demographic changes around them ( $\mathrm{H} 7$ rejected); this shows that the proposed mediation variable is not able to show a significant relationship to the final endogenous variable. Consequently, the absence of a relationship between mediating variables, the tendency of information dissemination, to the fear of demographic change makes all hypotheses containing indirect relationships in the model becoming insignificant (H8-H10 were rejected). After obtaining the significance results, we can evaluate the importance of each proposed hypothesis in their path coefficients.

The next step is to evaluate the path coefficient of the model proposed in this study. The path coefficient test shows how much influence each relationship between variables. This step is very important in the test of structural models because answering the hypothesis alone without looking at the relevance of the proposed variable or the contribution of the variable to other variables will reduce the explanatory power of the study because the magnitudes of influence between variables were an important indication for strategic decision making. Hair (2014: 175) states that small relevance power will not benefit managerial practices in the field; however, a behavioral study like this still could use the obtained results. The result of the path analysis was as follow: 


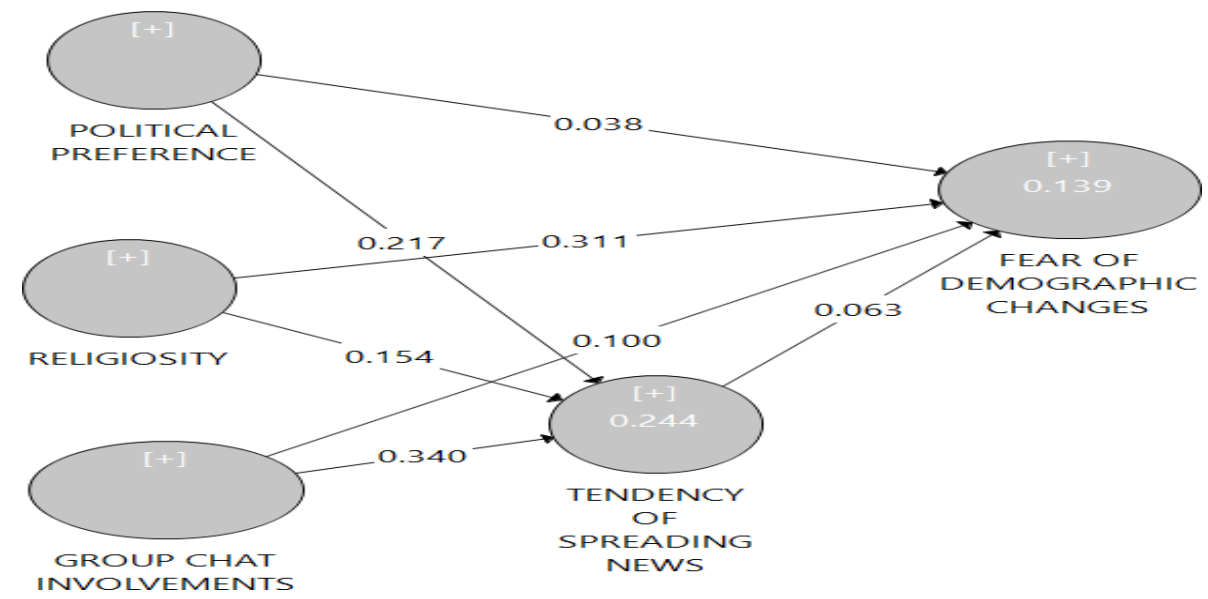

Figure 2. Path Coefficients

Figure 2 above contains two important pieces of information, namely the magnitude of the relationship between the variable and the R-value of the squares. The path coefficient can be assessed from the numbers listed on each arrow line on each variable. As for the value of $\mathrm{R}$ square can be seen in the numbers contained in the variable tendency of spreading news and fear of demographic changes.

The path coefficient results provide information that the magnitude of the influence of political choices on the tendency to spread the news is $21.7 \%$. There is a $15.4 \%$ potential that religious millennials will spread the news they get. there is also the probability for millennials involved in many chat groups to spread the information they get. A small role of $3.8 \%$ of political choices will lead to fears of the changing demographic environment of young people. Religious factors were found to have a significant role in driving fear of demographic change by $31.1 \%$. Involvement in many chat groups only has a $10 \%$ influence on fears of demographic change. The amount of information distributed has an effect of $6.3 \%$ on the fear of demographic changes. The indirect relationship between political choice, religiosity, and involvement in many chat groups will influence the fear of demographic change and the tendency to disseminate information by $3.2 \%, 2.6 \%$, and $4.8 \%$ respectively.

After conducting the multicollinearity test and structural model, the R2 test is the following output that provides information on the predictive ability of the proposed model. R2 is calculated based on the square of the actual and predicted values in the model, and from it, the effect of a combination of exogenous latent variables on endogenous latent variables is obtained. R2 values range from 0-1 where the closer the number 1, the greater the predictive ability of the model. Hair (2014: 176) states that a good model is a model that has a high predictive value (high R2) with few exogenous variables, or a parsimony model. The results of this study found the size of the $\mathrm{R}$ square from the exogenous variable to the tendency of information dissemination was $24.4 \%$, and $13.9 \%$ influence of all exogenous variables to the fear of demographic changes.

As it is inevitable, the use of social media certainly had its upside or downside effects. Knowledge dissemination, low-information barriers, and openness were some positivity of borderless news distributions, to name a few. However, they are 
costly. Proof of negativity came from the issues of mental health. A study of Primack et al (2017) demonstrated a higher level of anxiety among students, who used more social apps then the lesser one. The anxiety appeared to come from the quality of interaction in social media, instead of its quantity (Davila et al. 2012). It could also trigger stress in moderate form, as revealed by Pew Research Study's report (2015); furthermore, another study found a relationship with loneliness (Primack et al. 2017). Certainly, it also had a positive impact, as it could assist lonely people to be more open to others - leading to helpful conversations - that might help to remedy such issues (Berger \& Buechel, 2012). All of those studies shed light on the potentiality of the research agenda that might follow.

Speaking of gender, Correa, Hinsley, and Zuniga pointed extraverted men with emotional instability were more likely to use more social media (Correa, Hinsley, \& de Zúñiga, 2010). A political tendency toward conservatism was also found to spread more negative/junk news, post recent USA election, according to the latest study from Oxford (Narayanan et al., 2018). A study by Pew research center also highlighted the increase in spreading the news among lower-income people (Rainie \& Duggan, 2015). Another variable in this study is religiosity. The reason for employing this measure is because there is a growing movement in Indonesia to be more religious and conservative. The national election in 2014 and the case of Basuki Tjahaya Purnama (Ahok) blasphemy in 2017 further amplified this trend, resulting in a more divided religiosity, between conservative and moderate Moslems. Brossard et al. found that religiosity made people more resistant to technological changes - acting as a filter. However, a recent study in 2018 by Douglas of Cambridge University revealed that conservative people often used religious issues to propagate fake news (Douglas, 2018). In term of educational background, Pennycook and Rand argued that analytical thinking is the filter of fake news, but only if it is not related to their political preference; however, the phenomenon of spreading fake news among lecturers has become the shocking news headlines (Pennycook \& Rand, 2019). Involvement in group chats is also a recent trend in Indonesia. The authors' experiences in using Whatsapp group chats of lecturers have observed the tendency of users to forward news or thoughts, often characterized by long and attractive contents or even fake news.

The study itself found a positive role for the political choices of millennials in their tendency to spread information to others. This research compiles indicators of political choice that are open to liberal views. some statements such as support for the right to life of a lesbian, gay, bisexual and transgender (LGBT) or religious freedom were to name a few. Millennials are quite open about liberal issues, except LGBT issues. Millennials in this study agreed that LGBT people could not be supported. This fact is in line with a strong religious background and the majority of respondents who come from Islamic universities. This fairly open political choice actually encourages the potential dissemination of information by millennials. Diverse choices of media will encourage the increased political participation of individuals (Prior, 2005). This political participation will increase openness to information received by the public; in the case of this study, the view of millennials was leaning towards liberalism. Conservatives have a higher tendency to spread false news (Jost, van der Linden, Panagopoulos, \& Hardin, 
2018). Millennials who tend to be open also actively disseminate information, concurring with hypothesis 1 in this study. Conservatives have a higher tendency to spread false news (Jost, 2018). An open political perception is also not able to encourage fear of demographic changes. Although it is not in line with hypothesis 4 , an agreement is reached that the principle of openness will overcome the fear of demographic change itself. As liberals more open, their fear of demographic shifts was lower than the conservative one (Graham et al., 2009; Haidt \& Graham, 2007). This explanation can be an argument about hypotheses 4 and 8 .

Religious people were not associated with the tendency of spreading news as outlined in hypothesis 2 . This could be explained by their religious conduct to actively consider the upcoming information. The insignificant relationship clearly rejected the recently-constructed relationship in this study, rejecting hypothesis 2 . Religious people tend to filter information, even more, scientific information that could put their belief to question (Brossard, Scheufele, Kim, \& Lewenstein, 2009). This could be an explanation for our findings. One important thing to note was religiosity was found to significantly increase the fear of millennials in demographic changes, supporting Hypothesis 5. The prevalent fear of China's economic and political invasion to Indonesia seemed to affect the perception of millennials and thus could lead to demographic segregation to races, religions, etc. The absence of a relationship between mediating variable to endogenous variable also further led to the absence relationship between religiosity, tendency to spread news, and fear of demographic changes in an indirect relationship, rejecting hypothesis 9.

Participation in group chats was a common trait in using many chat-based applications. A study from the Royal Society of London found that the presence of group chat with a large number of participants would encourage "cacophony" or repetition of information conveyed, and low participation /capita (Nematzadeh et al., 2016). This provokes an "echo chamber", where information tends to repeat itself. The case of the United States election had brought forward the situation, where information was continuously bombarded, thus creating a belief of false information (Paul \& Matthews, 2017). This situation is defined as "firehose of falsehood", and associated with Russia as the main propagandist. This belief of false information could then be propagated to other news channels, supporting hypothesis 3 significant relationship of group chat involvements and tendency to spread the news. Millennials were not an exception. However, participation in group chats did not directly increase the fear of demographic changes, as conversation could be pretty random from daily life to business. Millennials were associated with young people enjoying their life, making the information of demographic shifting did not really come to their radars. This could explain the fact in the rejection of hypothesis 6 and 10 .

\section{CONCLUSION}

This study is still in the exploratory state; thus, the use of PLS-SEM was one of the main reasons. However, several important findings highlight how people with a political preference for liberal thoughts were also actively spread the news. The more millennials involved in group chats, the more they tended to spread the news. 
Religious people were more afraid of demographic changes, to no exception of millennials. young people must actively filter out the quality of information they receive. This research has many weaknesses that can be suggestions for improvement for subsequent research. A better questionnaire instrument design could be the next improvement. The selection of respondents with stronger religious backgrounds or good religious mastery can be the next interesting source of information. Future studies could address these issues.

\section{ACKNOWLEDGMENT}

The authors would like to conveys their gratitude to the Faculty of Islamic Economics and Business, Universitas Islam Negeri Alauddin Makassar for the support to present this paper in this international conference, or reputable journal.

\section{BIODATA}

Dr. Muhammad Wahyuddin Abdullah, SE., M.Si. is a lecturer of the Accounting Dept on Faculty of Islamic Economics and Business, Universitas Islam Negeri Alauddin Makassar, Indonesia. His research interests are mainly in the intersection of income smoothing, profits, and research methods.

Dr. Alim Syariati, SE., M.Si. is a lecturer of Strategic Management, and Research Methodology in Management Department on Faculty of Islamic Economics and Business, Universitas Islam Negeri Alauddin Makassar, Indonesia. He is currently assigned to the Economics Department.

\section{REFERENCES}

Atelsek, F. J., \& Schutz, W. C. (1959). Firo: A Three-Dimensional Theory of Interpersonal Behavior. The American Catholic Sociological Review. https://doi.org/10.2307/3708975

Berger, J., \& Milkman, K. L. (2012). What makes online content viral? Journal of Marketing Research. https://doi.org/10.1509/jmr.10.0353

Brossard, D., Scheufele, D. A., Kim, E., \& Lewenstein, B. V. (2009). Religiosity as a perceptual filter: Examining processes of opinion formation about nanotechnology. Public Understanding of Science, 18(5), 546-558. https://doi.org/10.1177/0963662507087304

Caprara, G. V., \& Zimbardo, P. G. (2004). Personalizing politics: A congruency model of political preference. American Psychologist, 59(7), 581-594. https://doi.org/10.1037/0003-066X.59.7.581

Correa, T., Hinsley, A. W., \& de Zúñiga, H. G. (2010). Who interacts on the Web?: The intersection of users' personality and social media use. Computers in Human Behavior. https://doi.org/10.1016/j.chb.2009.09.003

Douglas, C. (2018). $\square$ Christopher Douglas $\mid 6$ January 2018. (January), 1-15.

Fornell, C., \& Larcker, D. F. (1981). Evaluating structural model with unobserved variables and measurement errors. Journal of Marketing Research.

Geertz, C. (2013). Religion as a cultural system. In Anthropological Approaches to the Study of Religion. https://doi.org/10.4324/9781315017570 
Glock, C. Y. (1962). On the study of religious commitment. Religious Education. https://doi.org/10.1080/003440862057S407

Graham, J., Haidt, J., \& Nosek, B. A. (2009). Liberals and Conservatives Rely on Different Sets of Moral Foundations. Journal of Personality and Social Psychology. https://doi.org/10.1037/a0015141

Haerani, S., Parmitasari, R. D. A., Aponno, E. H., \& Aunalal, Z. I. (2019). Moderating effects of age on personality, driving behavior towards driving outcomes. International Journal of Human Rights in Healthcare. https://doi.org/10.1108/IJHRH-08-2017-0040

Haidt, J., \& Graham, J. (2007). When morality opposes justice: Conservatives have moral intuitions that liberals may not recognize. Social Justice Research. https://doi.org/10.1007/s11211-007-0034-z

Hair, J. F., Risher, J. J., Sarstedt, M., \& Ringle, C. M. (2019). When to use and how to report the results of PLS-SEM. European Business Review. https://doi.org/10.1108/EBR-11-2018-0203

Hargittai, E., Gallo, J., \& Kane, M. (2008). Cross-ideological discussions among conservative and liberal bloggers. Public Choice. https://doi.org/10.1007/s11127-007-9201-x

Herdiansah, A. G., Putri, D. A., Ashari, L., \& Maduratmi, R. (2017). The Islam Defence Action: A Challenge of Islamic Movement to Democratic Transition in the Post 2014 Indonesia. Jurnal Penelitian Ilmu-Ilmu Sosial, 20(2), 57-67.

Ho, J. Y. C., \& Dempsey, M. (2010). Viral marketing: Motivations to forward online content. Journal of Business Research. https://doi.org/10.1016/j.jbusres.2008.08.010

Huber, L. P. (2016). Make America Great Again_Trump, Racist Nativism. Charleston Law Review, 10, 215-248.

Inbar, Y., Pizarro, D. A., \& Bloom, P. (2009). Conservatives are more easily disgusted than liberals. Cognition and Emotion. https://doi.org/10.1080/02699930802110007

Jost, J. T., van der Linden, S., Panagopoulos, C., \& Hardin, C. D. (2018). Ideological asymmetries in conformity, desire for shared reality, and the spread of misinformation. Current Opinion in Psychology, 23, 77-83. https://doi.org/10.1016/j.copsyc.2018.01.003

Ketchen, D. J. (2013). A Primer on Partial Least Squares Structural Equation Modeling. In Long Range Planning (Vol. 46). https://doi.org/10.1016/j.lrp.2013.01.002

Kurniasih, N., \& Riyadhsyah, T. (2018). Virtual Ethnography Study of Interlecturer Communication in National Young Lecturers Forum WhatsApp Group. https://doi.org/10.2991/icaaip-17.2018.10

Lim, M. (2017). Freedom to hate: social media, algorithmic enclaves, and the rise of tribal nationalism in Indonesia. Critical Asian Studies. https://doi.org/10.1080/14672715.2017.1341188

Loewenstein, G. (1994). The psychology of curiosity: A review and reinterpretation. Psychological Bulletin. https://doi.org/10.1037/00332909.116.1.75

MASTEL. (2017). Hasil Survey Mastel Tentang Wabah Hoax Nasional. Mastel, 
18. Retrieved from http://mastel.id/press-release-infografis-hasil-surveymastel-tentang-wabah-hoax-nasional/

Narayanan, V., Barash, V., Kelly, J., Kollanyi, B., Neudert, L.-M., \& Howard, P. N. (2018). Polarization, Partisanship and Junk News Consumption over Social Media in the US. 1-6. Retrieved from http://arxiv.org/abs/1803.01845

Nematzadeh, A., Ciampaglia, G. L., Ahn, Y.-Y., \& Flammini, A. (2016). Information Overload in Group Communication: From Conversation to Cacophony in the Twitch Chat. Retrieved from http://arxiv.org/abs/1610.06497

Outten, H. R., Schmitt, M. T., Miller, D. A., \& Garcia, A. L. (2012). Feeling threatened about the future: Whites' emotional reactions to anticipated ethnic demographic changes. Personality and Social Psychology Bulletin, 38(1), 14-25. https://doi.org/10.1177/0146167211418531

Parmitasari, R. D. A., Alwi, Z., \& S., S. (2018). Pengaruh Kecerdasan Spiritual dan Gaya Hidup Hedonisme terhadap Manajemen Keuangan Pribadi Mahasiswa Perguruan Tinggi Negeri di Kota Makassar. Jurnal Minds: Manajemen Ide Dan Inspirasi. https://doi.org/10.24252/minds.v5i2.5699

Paul, C., \& Matthews, M. (2017). The Russian "Firehose of Falsehood" Propaganda Model: Why It Might Work and Options to Counter It. The Russian "Firehose of Falsehood" Propaganda Model: Why It Might Work and Options to Counter It. https://doi.org/10.7249/pe198

Pennycook, G., \& Rand, D. G. (2019). Who falls for fake news? The roles of bullshit receptivity, overclaiming, familiarity, and analytic thinking. Journal of Personality, (September). https://doi.org/10.1111/jopy.12476

Prior, M. (2005). News vs. entertainment: How increasing media choice widens gaps in political knowledge and turnout. American Journal of Political Science. https://doi.org/10.1111/j.1540-5907.2005.00143.x

Rainie, L., \& Duggan, M. (2015). About the Pew Research Center. Privacy and Information Sharing, (2014).

Raja Zulkifi, R. N., Mohd Sani, M. A., Muhamad, H., \& Ahmad, N. S. Y. (2018). Satira Politik: Analisis Internet Trolling di Malaysia. Jurnal Komunikasi, Malaysian Journal of Communication. https://doi.org/10.17576/jkmjc-20183402-14

Sabatini, F., \& Sarracino, F. (2014). Fabio Sabatini and Francesco Sarracino Online networks and subjective well-being EERI.

Salman, A., Mustaffa, N., ... Ali, M. N. S. (2016). Social Media and Agenda Setting: Implications on Political Agenda. Jurnal Komunikasi, Malaysian Journal of Communication. https://doi.org/10.17576/jkmjc-2016-3201-19 